Political Science, Union College, Schenectady, New York 12308.

R. Douglas Arnold

Princeton University

James E. Underwood

Union College

\section{Harold Webb, Jr.}

Harold "Chick" Webb, Jr., professor emeritus at Duquesne University in Pittsburgh, died January 22, 1994, of lymphoma. Dr. Webb, 68 , taught political science at Duquesne for 34 years, specializing in international relations.

He served at one time as associate editor of the "Duquesne Review" and conducted research on the Liberal Party of Great Britain. He wrote articles and gave lectures on Catholic higher education. He was one of three professors offering a team-taught Introduction to Political Science course at Duquesne, and was considered one of the finest teachers at that university.

Webb, a native of Philadelphia, received his bachelor's and master's degrees from the University of Pennsylvania, and his doctorate from Brown University. He spent two years as a Fulbright Scholar in London. He was awarded a Purple Heart for his service with the U.S. Army 14th Armored Division in France during World War II.

Webb suffered a sight impairment due to injuries from that war. His wife, Katherine Kinniry Webb, read books onto tapes for Webb to "read," and read student term papers to him so that Webb could grade them. Webb is survived by his widow; three sons, Robert, Timothy, and Richard; one daughter, Karen A. Webb; a sister, Nancy; and five grandsons.

Pat Dunham

Duquesne University

\section{Frederick L. Zimmermann}

We regret the passing of Frederick L. Zimmermann, a long-time member of the American Political Science Association and of the political science faculty at Hunter College in New York City. Born in Brooklyn, New York, Professor Zimmermann received a B.A. in 1928 and an M.A. in 1930 from Columbia University. He was elected to six one-year terms in the New York State Assembly between 1930 and 1935 . In 1936 he joined the faculty of Hunter College and continued to teach there until his retirement in 1970. From 1960 until 1969, Fred served as chair of the Hunter political science department.

Shortly after his retirement, he left New York City to live in a part of the world that he deeply loved: the Hudson River Valley south of Albany.

During his years at Hunter, Fred's courses in American national government, state government, political parties, and federalism were amongst the most popular given by the political science department. He brought to the classroom not only scholarly understanding but practical knowledge drawn from his years in the New York State Legislature. One unusual feature of Fred's service is that during his first decade or more at Hunter he was the only man in a department composed entirely of women. Founded in 1870, Hunter was a college for women until the late 1960 s when men were first admitted as students at the Park Avenue campus in Manhattan. It apparently was the policy of the college for many decades not to appoint men to the college faculty (though its early presidents were all men).

Fred Zimmermann was one of the nation's leading authorities on American federalism. His particular field of expertise was the interstate compact. At a time when such agreements were relatively rare, Fred was a forceful advocate of their use by the states as a means to resolve common problems. In 1951 and again ten years later, he published books for the Council of State Governments (in collabora- tion with his friend Mitchell Wendell) on interstate compacts. In addition, he wrote many scholarly articles (again often with Mitchell Wendell) on interstate compacts that appeared in such journals as State Government, Columbia Law Review, Georgetown Law Journal, Western Political Science Quarterly, and the American Political Science Review.

In addition to his teaching and writing, Fred was called upon by many governmental agencies to provide knowledge and advice about specific intergovernmental problems. For more than three decades, Fred served as a consultant to such organizations as the New York State Legislature, the United States Department of State, the Atlantic States Marine Fisheries Commission, the Interstate Commission on the Delaware Basin, the Port of New York Authority, and the Association of Attorneys General. Fred was one of the founders of the Council of State Governments and played an important part in initiating and drafting a large number of interstate compacts, including: the Atlantic State Marine Fisheries Compact (1941), the Gulf States Marine Fisheries Compact (1946), the Interstate Civil Defense Compact (1950), the Tennessee River Basin Pollution Abatement Compact (1957), the Great Lakes Basin Compact (1957), and the Detainer Compact (1957).

But those of us who served with Fred in the Department of Political Science will remember him as a kind, gentle, caring friend and associate. As a new member of the department in the mid-1960s, I recall his special concern for the junior members of the faculty. His knowledge and encouragement played an important part in providing a foundation for my career as a college professor. He will long be remembered by me, by his other former colleagues, and by his many friends.

Walter E. Volkomer Hunter College 